\title{
Tracheal bronchus and disseminated tuberculosis in a 9-year-old girl: incidental finding or association?
}

\author{
Santhiya Srinivasan, Joseph L Mathew, Pankaj C Vaidya, Meenu Singh
}

Pediatrics, Post Graduate Institute of Medical Education and Research, Chandigarh, India

Correspondence to Professor Joseph L Mathew; dr.joseph.I.mathew@gmail.com

Accepted 8 January 2020

\section{DESCRIPTION}

We present a 9-year-old girl, who had pain abdomen and weight loss for 3 months, followed by cough for 3 weeks and vomiting for 3 days. There was no history of abdominal distension, constipation, bone pain or bleeding from any site. There was no history of contact with tuberculosis. On examination, she was severely malnourished and pale. Systemic examination revealed doughy abdomen, hepatomegaly and fine crackles in the right mammary area. Initially, abdominal and pulmonary tuberculosis was considered. Her tuberculin skin test was negative, and sputum examinations were thrice negative for tuberculosis. HIV I/II serologies were negative. Chest radiography revealed inhomogeneous opacity in the right and the left upper zone. Abdominal ultrasonography revealed mild ileal loop thickening and appendiceal inflammation. Flexible fibreoptic videobronchoscopy revealed a right upper lobe bronchus arising proximal to the carina (figure 1A). It had three openings corresponding to the segments of the right upper lobe (figure 1B). The bronchus intermedius was present in the usual location of the right main bronchus. The left-sided bronchial anatomy was normal. Bronchoalveolar lavage fluid revealed tuberculosis bacilli confirming the diagnosis. Antituberculosis therapy resulted in resolution of symptoms.

Tracheal bronchus (pig bronchus) is a rare congenital anomaly, where the right upper lobe bronchus originates directly from the trachea rather than the right main bronchus. ${ }^{1}$ The reported incidence is less than $2 \% .^{2}$ It can be asymptomatic and diagnosed incidentally during bronchoscopy. Occasionally, it might present with symptoms like

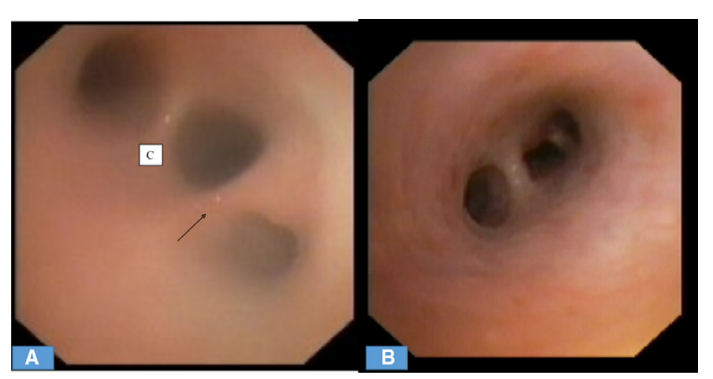

Figure 1 (A) Bronchoscopy revealing tracheal bronchus in the right side (arrow) and carina (C). (B) Tracheal bronchus revealing three divisions for the right upper lobe.

\section{Learning points}

- Most of the cases of tracheal bronchus are asymptomatic and detected incidentally.

- Tracheal bronchus should be included in the differential diagnosis of a child presenting with right upper lobe pneumonia or collapse particularly with other congenital anomalies.

stridor or recurrent pneumonia. Recognising the tracheal bronchus during endotracheal intubation is important, ${ }^{3}$ because the endotracheal tube can obstruct the tracheal bronchus, causing collapse of the right upper lobe. Accidental intubation of the tracheal bronchus can cause pneumothorax and inadequate aeration of remaining part of the tracheobronchial tree. Flexible bronchoscopy helps in visualising the bronchial segments within the tracheal bronchus. ${ }^{3}$ In our index case, tracheal bronchus was detected incidentally by flexible bronchoscopy for the evaluation of tuberculosis. Hence, it is an incidental finding rather than an association with tuberculosis. Management of tracheal bronchus depends on the severity of the symptoms. In case of recurrent severe infections, resection of the anomalous bronchus and lobe is the treatment of choice. $^{13}$

Contributors SS: patient management, literature review and the initial draft of manuscript preparation. JLM: contribution of fibre optic bronchoscopy, critical review of the manuscript for important intellectual content and final approval of the version to be published. He will act as a guarantor of the manuscript. PCV: patient management, critical review of the manuscript for important intellectual content and final approval of the version to be published. MS: clinician in charge, critical review of the manuscript for important intellectual content and final approval of the version to be published.

Funding The authors have not declared a specific grant for this research from any funding agency in the public, commercial or not-for-profit sectors.

Competing interests None declared.

Patient consent for publication Obtained.

Provenance and peer review Not commissioned; externally peer reviewed.

\section{REFERENCES}

1 Barat M, Konrad HR. Tracheal bronchus. Am J Otolaryngol 1987;8:118-22.

2 Ghaye B, Szapiro D, Fanchamps JM, et al. Congenital bronchial abnormalities revisited. Radiographics 2001;21:105-19.

3 Doolittle AM, Mair EA. Tracheal bronchus: classification, endoscopic analysis, and airway management. Otolaryngol Head Neck Surg 2002;126:240-3. 
Copyright 2020 BMJ Publishing Group. All rights reserved. For permission to reuse any of this content visit https://www.bmj.com/company/products-services/rights-and-licensing/permissions/

BMJ Case Report Fellows may re-use this article for personal use and teaching without any further permission.

Become a Fellow of BMJ Case Reports today and you can:

- Submit as many cases as you like

Enjoy fast sympathetic peer review and rapid publication of accepted articles

Access all the published articles

- Re-use any of the published material for personal use and teaching without further permission

Customer Service

If you have any further queries about your subscription, please contact our customer services team on +44 (0) 2071111105 or via email at support@bmj.com.

Visit casereports.bmj.com for more articles like this and to become a Fellow 